\title{
REVIEW
}

\section{Clinical review: Probiotics in critical care}

\author{
Neil H Crooks ${ }^{* 1}$, Catherine Snaith', Deborah Webster ${ }^{2}$, Fang Gao ${ }^{3}$ and Peter Hawkey,
}

\begin{abstract}
Patients in ICUs represent a relatively small subgroup of hospitalised patients, but they account for approximately $25 \%$ of all hospital infections. Approximately $30 \%$ of ICU patients suffer from infection as a complication of critical illness, which increases the length of ICU stay, morbidity, mortality and cost. Gram-negative bacteria are the predominant cause of ICU-related infections and with the rise in multidrug-resistant strains we should focus our attention on nonantibiotic strategies in the prevention and treatment of nosocomial infections. Probiotics have been proposed as one option in this quest; however, mechanisms of action in the critically ill population require further investigation. Some of the beneficial effects appear to be associated with improvement in gastrointestinal barrier function, restoration of normal intestinal permeability and motility, modification of the balance of intestinal microbiota and immunomodulation. However, the information we have to date on the use of probiotics in the critical care setting is difficult to interpret due to small sample sizes, differences in ICU populations, the variety of probiotic combinations studied and differences in administration techniques. In this review we shall examine the use of probiotics in the critical care setting, look at some of the proposed mechanisms of action and discuss their potential benefits and drawbacks.
\end{abstract}

\section{Introduction}

During an episode of critical illness a number of significant changes occur in the microbiota of the human gut. These changes occur due to alterations in the stress hormone profile, impairment of blood supply to the gut,

*Correspondence: nhcrooks@gmail.com

'Academic Department of Anaesthesia, Critical Care and Pain, Heart of England NHS Foundation Trust, Birmingham Heartlands Hospital, Bordesley Green East, Birmingham B9 5SS, UK

Full list of author information is available at the end of the article immunosuppression, antibiotic use and nutrient deficiency [1]. In experimental models these changes have been shown to occur within 6 to 8 hours, with endogenous Lactobacillus strains being replaced by pathogenic bacteria [2]. This change can lead to a breakdown in the intestinal barrier function that is likely to play a significant role in the pathogenesis of multiple organ dysfunction syndrome $[3,4]$.

Redressing this balance and exploiting the beneficial effects of probiotic bacteria is understandably an area of considerable interest. However, the mechanisms by which these microorganisms exert their effects are various and depend upon the dose used, the route(s) of administration and the dosing frequency [5]. Furthermore, a number of these effects are strain specific.

\section{Probiotics, prebiotics and synbiotics}

Probiotics are defined as live microorganisms that confer a health benefit on the host when administered in adequate amounts' [6]. Prebiotics are nondigestible food components that stimulate the growth and/or activity of bacteria in the digestive tract in ways that may be beneficial to health [7]. Synbiotics are a combination of probiotics and prebiotics. There has been an explosion of interest in probiotics and their potential health benefits since 2000, with initial attention focusing on the gastrointestinal tract.

\section{Probiotics and the gastrointestinal tract}

The human intestine is home to hundreds of species of bacteria, archaea and eukarya, many of which are nonculturable but can now be identified using metagenomic approaches. The bacterial load tends to be highest in the large intestine (up to $10^{11}$ colony-forming units/g), and while the healthy human gut is dominated by Bacteroides, Firmicutes and Actinobacteria, each individual has their own distinct stool bacterial composition determined by environmental and genetic factors. This bacterial profile remains relatively constant over time unless altered by disease state or antibacterial treatment $[8,9]$.

Culture-based and molecular detection methods have demonstrated that it is possible to significantly alter the composition of gut flora in adults and infants by treatment with probiotics. Sepp and colleagues treated 15 neonates with Lactobacillus rhamnosus GG for the first 
2 weeks of life. They found that L. rhamnosus GG persisted for 1 month in eight of these neonates. There were also significant differences in the bacterial composition of the stool compared with the control group, with increased numbers of coliforms, lactobacilli and Bifidobacterium spp. [10]. Benno and colleagues demonstrated a statistically significant increase in bifidobacteria in adults treated with $L$. rhamnosus GG for a 4-week period. They also found an increase in lactobacilli and a decrease in the proportion of Clostridium spp. [11]. As these techniques are based on faecal profiling, they tend to reflect the large bowel bacterial composition with little information being available on the small bowel effects of probiotics.

\section{Mechanisms of action of probiotics}

Much of the information available on the mechanisms of action of probiotics is obtained from animal work and in vitro studies; hence we must be careful in extrapolating this to humans. What is clear, however, is that there are multiple mechanisms by which different probiotic bacteria exert their effects, and these effects may vary with the strain and population studied. Table 1 summarises the main mechanisms by which probiotics exert their effects, and Table 2 presents details of commonly used probiotic preparations.

Probiotics may alter the local environment within the lumen of the gut, producing antimicrobial effects on pathogenic organisms. Lactic acid-producing and acetic acid-producing probiotics reduce the luminal $\mathrm{pH}$ resulting in an unfavourable milieu for pathogens. This has been demonstrated in vitro with pathogen growth being reduced in a $\mathrm{pH}$-dependent manner by Lactobacillus spp. [12]. Venturi and colleagues demonstrated a significant reduction of luminal $\mathrm{pH}$ in vivo in ulcerative colitis patients treated with the probiotic mixture VSL\#3 [13].

Probiotics also exert a direct antimicrobial effect via the production of bacteriocins. Bacteriocins are proteins produced by bacteria that inhibit the growth and virulence of other pathogenic bacteria. Probiotic bacteria deficient in the bacteriocin gene are less effective probiotics, as demonstrated in a murine model where a mutant form of Lactobacillus salivarius UCC118 failed to protect against infection with Listeria monocytogenes [14]. A wide variety of bacteriocins is recognised, and their spectrum of action ranges from antagonism of similar bacterial strains to the inhibition of a wide range of Gram-positives, Gram-negatives, yeasts and moulds [15]. One such example of a broad-spectrum bacteriocin is that produced by a subspecies of $L$. salivarius. The ABP-118 bacteriocin inhibits Bacillus, Staphylococcus, Enterococcus, Listeria and Salmonella spp. [16].

Bacteria communicate with each other using a mechanism known as quorum sensing. This involves the production and secretion of signalling molecules known as autoinducers. In their in vitro study, Medellin-Peña and colleagues demonstrated that Lactobacillus acidophilus La-5 secretes molecules that disrupt this interbacterial communication, reducing expression of virulence-related genes by Escherichia coli O157:H7 [17].

Probiotics have also been demonstrated to enhance intestinal barrier function. Intestinal barrier function is complex and its control involves cellular stability at a cytoskeletal and tight junction level, as well as mucus, chloride and water secretion. Probiotics have been shown to exert an effect, in vitro and in vivo, via these mechanisms [15]. For example, Lactobacillus plantarum 299v can enhance mucus production and secretion in human intestinal epithelial cells [18]. The probiotic strain E. coli Nissle 1917 appears to enhance mucosal barrier function by production of human $\beta$-defensin 2 [15]. E. coli Nissle has also has been demonstrated in vitro to reduce adhesion and invasion of intestinal epithelial cells by an enteroinvasive $E$. coli.

In addition, by competing with pathogens for nutrients and adhesion in a microbiological niche, probiotics can prevent replication by pathogens, a phenomenon known as colonisation resistance [5]. Probiotics can thus promote the integrity of the gut defence barrier and create an unfavourable environment for pathogen colonisation.

Probiotics can also exert a range of immunological effects. The interaction between the luminal bacteria and the underlying epithelial and mucosal lymphoid cells is referred to as bacterial-epithelial cross-talk. This crosstalk enables probiotics to have an effect on both the innate and adaptive host immune system [19] - for example, promotion of $B$ cells into plasma cells, increased production of secretory immunoglobulin A and prevention of activation of the proinflammatory nuclear transcription factor NF- $\mathrm{kB}$ [5]. Other immunologic mechanisms include alteration of the cytokine profile and activation of macrophages to present antigen to B lymphocytes and increase immunoglobulin production [20].

\section{Probiotics in the critically ill}

The efficiency of intestinal barrier function is demonstrated by the fact that the faecal bacterial concentration approaches $10^{12}$ organisms $/ \mathrm{ml}$ in the caecum, while tissues one cell deep to the intact intestinal mucosa are usually sterile [21]. Any significant insult to the gut or alteration to its microbiota is likely to play a role in promoting systemic inflammation and infection in the critically ill population [22]. In contrast to the large bowel, the stomach, duodenum and jejunum have a relative paucity of bacteria $\left(10^{3}\right.$ to $10^{4}$ organisms $\left./ \mathrm{ml}\right)$. The presence of enteric organisms in gastric aspirates is therefore abnormal and represents gastric colonisation. In the context of critical illness, this colonisation is the result of bacterial overgrowth in the proximal gastrointestinal tract [21]. 
Table 1. Summary of mechanisms of action for probiotics

\begin{tabular}{ll}
\hline Mechanism of action & \\
\hline Luminal pH modification & $\begin{array}{l}\text { Production of lactic acid and acetic acid reduces } \\
\text { luminal pH resulting in unfavourable milieu for } \\
\text { pathogens }\end{array}$ \\
Bacteriocin production & $\begin{array}{l}\text { Bacteriocins are proteins produced by bacteria } \\
\text { that inhibit the growth and virulence of other } \\
\text { microorganisms. The may be narrow spectrum (inhibit } \\
\text { related bacterial strains) or broad spectrum (inhibit a } \\
\text { wide range of bacteria, yeasts and moulds) [15] }\end{array}$ \\
$\begin{array}{l}\text { Disruption of } \\
\text { interbacterial } \\
\text { communication }\end{array}$ & $\begin{array}{l}\text { Autoinducers are the signalling molecules produced } \\
\text { and secreted by bacteria that form the basis of } \\
\text { quorum sensing (bacterial communication) }\end{array}$ \\
$\begin{array}{l}\text { Enhanced mucosal } \\
\text { barrier function }\end{array}$ & $\begin{array}{l}\text { Increased intestinal epithelial cell mucus production } \\
\text { and secretion }\end{array}$
\end{tabular}

Reduced adhesion and invasion of intestinal epithelial cells by enteroinvasive bacteria resulting in reduced translocation

Increased production of human $\beta$-defensin 2 by epithelial cells

Stabilisation of intracellular tight junctions and reduced chloride/water secretion

Epithelial cell regeneration and reduced apoptosis

Colonisation resistance The probiotic competes with pathogen for nutrients and adhesion in a microbiological niche [5]

Immunological effects

Bacterial-epithelial cross-talk enables luminal probiotic organisms to influence gut-associated lymphoid tissue and innate and adaptive host responses $[19,85]$. Toll-like receptors play a central role in mediating this process [86]

Increased promotion of B cells to plasma cells and increased production of immunoglobulins [5]

Activation and modulation of macrophages, T cells and natural killer cells

\section{Specific probiotic examples}

Lactobacillus spp.: pH-dependent reduction in pathogen growth [12]

VSL\#3: in vivo luminal pH reduction in ulcerative colitis patients [13]

Mutant Lactobacillus salivarius deficient in bacteriocin gene are unable to protect mice against Listeria monocytogenes infection [14]

L. salivarius subspecies produce broad-spectrum bacteriocins [16]

Lactobacillus acidophilus La-5 disrupts quorum sensing and expression of virulence-related genes by Escherichia coli 0157:H7 [17]

Lactobacillus plantarum 299v: increased mucin gene expression in vitro [18] and adherence to colonic cells via a mannose-specific adherence mechanism [74]

Lactobacillus casei rhamnosus adheres to colonic cells in vitro [75]

E. coli Nissle 1917: increase in mucin gene expression [76] and production of human $\beta$-defensin 2 by colonic cells [77]

Streptococcus thermophiles and L. acidophilus reduce water and chloride secretion in response to pathogenic bacteria $[78,79]$

Lactobacillus pretreatment of intestinal epithelium reduces disruption of epithelial tight junctions by pathogenic E. coli [80]. Probiotic preparation VSL\#3 (see Table 2) prevents redistribution of epithelial tight junction proteins on exposure to pathogenic bacteria [76]. Lactobacillus rhamnosus GG prevents cytokine-mediated apoptosis of intestinal epithelial cells [81] Lactobacillus casei and Clostridium butyricum both stimulate gut epithelial proliferation in rats [82]

L. casei rhamnosus adheres to colonic cells, reduces pathogenic bacterial growth and can persist within the gastrointestinal tract $[75,83]$

E. coli Nissle 1917 inhibits growth of Shiga-toxin producing E. coli [84]

VSL\#3 has been associated with increased anti-inflammatory and reduced proinflammatory cytokine activity, reduced inducible nitric oxide synthase and matrix metalloproteinase activity in patients with pouchitis [87].

L. plantarum 299v increases IL-10 secretion from macrophages and T cells in patients with ulcerative colitis [88]. L. casei and Lactobacillus bulgaricus significantly reduce TNFa release from inflamed mucosa in Crohn's disease [89]. E. coli Nissle 1917 shows local and systemic anti-inflammatory effects in a murine model of lipopolysaccharide-induced sepsis [90]

L. rhamnosus GG: increased circulating lgA, IgG and lgM concentrations in children with gastroenteritis [91,92]. Pretreatment with probiotic prior to typhoid vaccination leads to increased anti-typhoid antibody titres [93]

L. casei Shirota: cell wall structure potently induces IL-12 production and the probiotic differentially controls the inflammatory cytokine responses of macrophages, T cells and natural killer cells $[30,94,95]$. L. casei Shirota and Bifidobacterium breve administered preoperatively to biliary cancer patients significantly reduce postoperative IL-6, C-reactive protein and white cell count concentrations [30]. L. acidophilus and Bifidobacterium longum increased macrophage phagocytic activity in a murine model [96]
Colonisation of the stomach by pathogens or potential pathogens is believed to occur due to a combination of poor gut motility, increased gastric $\mathrm{pH}$ (due to acid suppression) and the use of broad-spectrum antibiotics. This combination of factors leads to an overgrowth of bacteria in the duodenum, which reflux into the stomach and are ultimately regurgitated and aspirated into the lungs [23].

The normal intestinal microbiota of critically ill patients is altered and replaced by pathogens for a number of reasons. Therefore, it would seem logical to consider that probiotics may have a role in reducing intestinal 
Table 2. Summary of probiotic preparations

\begin{tabular}{|c|c|c|}
\hline Probiotic & Constituents & Administration example and dosing comments \\
\hline $\begin{array}{l}\text { Antibiophilus (Lcr35) } \\
\text { (Germania Pharmazeutika GesmbH, } \\
\text { Vienna, Austria) }\end{array}$ & Lactobacillus casei rhamnosus & $10^{9} \mathrm{CFU}$ twice daily via nasogastric tube [75] \\
\hline $\begin{array}{l}\text { Ecologic } 641 \\
\text { (Winclove Bio Industries, } \\
\text { Amsterdam, the Netherlands) }\end{array}$ & $\begin{array}{l}\text { Six different strains of bacteria: Lactobacillus } \\
\text { acidophilus, Lactobacillus casei, Lactobacillus } \\
\text { salivarius, Lactococcus lactis, Bifidobacterium } \\
\text { bifidum, and Bifidobacterium lactis (previously } \\
\text { classified as Bifidobacterium infantis), plus } \\
\text { cornstarch and maltodextrins }\end{array}$ & $\begin{array}{l}\text { Administered twice daily via nasojejunal tube to a total daily } \\
\text { dose of } 10^{10} \text { bacteria [35] }\end{array}$ \\
\hline $\begin{array}{l}\text { Ergyphilus } \\
\text { (Nutergia, Capdenac, France) }\end{array}$ & $\begin{array}{l}\text { Predominantly Lactobacillus rhamnosus GG, but } \\
\text { also L. casei, L. acidophilus and B. bifidum }\end{array}$ & $\begin{array}{l}\text { One capsule contains } 2 \times 10^{10} \text { lyophilised bacteria. Capsules can } \\
\text { be broken and given via enteral feeding tube. Five capsules } \\
\text { administered over } 24 \text { hours in critically ill patients [53] }\end{array}$ \\
\hline $\begin{array}{l}\text { Mutaflor } \\
\text { (Ardeypharm GmbH, Herdecke, } \\
\text { Germany) }\end{array}$ & Escherichia coli Nissle 1917 & $\begin{array}{l}2.5 \times 10^{9} \text { to } 25 \times 10^{9} \text { bacteria per capsule. Adult dose } 1 \text { or } 2 \\
\text { capsules per day [97] }\end{array}$ \\
\hline $\begin{array}{l}\text { Proviva } \\
\text { (Skanemejerier, Malmo, Sweden) }\end{array}$ & Lactobacillus plantarum 299v and oatmeal & $\begin{array}{l}\text { Oatmeal-based drink containing } 5 \times 10^{7} \mathrm{CFU} / \mathrm{ml} \text {. Dose of } 500 \mathrm{ml} \\
\text { used by McNaught and colleagues [24] }\end{array}$ \\
\hline $\begin{array}{l}\text { Synbiotic } 2000 \text { (Medipharm, } \\
\text { Kagerod, Sweden } \\
\text { and Des Moines, IA, USA) }\end{array}$ & $\begin{array}{l}\text { A probiotic mixture comprising Pediacoccus } \\
\text { pentosaceus 5-33:3, Leuconostoc mesenteroides } \\
\text { 77:1, Lactobacillus paracasei ssp., paracasei F19, } \\
\text { L. plantarum } 2362 \text { plus } \beta \text {-glucan, inulin, pectin and } \\
\text { resistant starch }\end{array}$ & Administered twice daily via feeding tube or orally [32] \\
\hline $\begin{array}{l}\text { Synbiotic } 2000 \text { Forte } \\
\text { (Medipharm, Kagerod, Sweden } \\
\text { and Des Moines, IA, USA) }\end{array}$ & $\begin{array}{l}\text { A probiotic mixture comprising P. pentosaceus } \\
\text { 5-33:3, L. mesenteroides 32-77:1, L. paracasei ssp. } \\
\text { paracasei } 19 \text { and L. plantarum 2362, plus inulin, oat } \\
\text { bran, pectin and resistant starch }\end{array}$ & $\begin{array}{l}\text { Sachet for reconstitution containing } 10^{10} \text { each bacteria plus } 10 \mathrm{~g} \\
\text { prebiotic fibre. Administered in doses of } 12 \mathrm{~g} \text { ( } 1 \text { sachet) per day } \\
\text { for a 15-day study period [47] }\end{array}$ \\
\hline $\begin{array}{l}\text { Trevis } \\
\text { (Christen Hansen, Hørsholm, Denmark) }\end{array}$ & $\begin{array}{l}\text { L. acidophilus La5, Lactobacillus bulgaricus, B. lactis } \\
\text { Bb-12 and Streptococcus thermophilus }\end{array}$ & $4 \times 10^{9} \mathrm{CFU} /$ capsule. One capsule three times daily $[25,26]$ \\
\hline \multirow[t]{2}{*}{$\begin{array}{l}\text { VSL\#3 } \\
\text { (Ferring Pharmaceuticals, } \\
\text { West Drayton, UK) }\end{array}$} & \multirow[t]{2}{*}{$\begin{array}{l}\text { Four strains of Lactobacillus (L. acidophilus, L. casei, } \\
\text { L. plantarum, Lactobacillus delbrueckii), three strains } \\
\text { of Bifidobacterium (B. infantis, Bifidobacterium } \\
\text { longum, Bifidobacterium breve) and one strain of } \\
\text { Streptococcus salivarius subsp. Thermophilus }\end{array}$} & $\begin{array}{l}\text { Powder for reconstitution with water or to be mixed with cold } \\
\text { foods prior to consumption. One sachet contains } 4.5 \times 10^{11} \text { lactic } \\
\text { acid bacteria. Also available as a capsule containing } 2.25 \times 10^{11} \\
\text { bacteria }\end{array}$ \\
\hline & & $\begin{array}{l}\text { Adult dose } 0.5 \text { to } 8 \text { sachets ( } 2 \text { to } 32 \text { capsules) per day depending } \\
\text { upon disease activity. Six grams once a day for } 12 \text { months } \\
\text { administered by Venturi and colleagues [13] }\end{array}$ \\
\hline
\end{tabular}

CFU, colony-forming units.

colonisation by pathogens and thus in the prevention of infection and sepsis syndromes in this population.

\section{Probiotics in the prevention of nonrespiratory infection}

Probiotics have been studied in the prevention of postoperative infection. Three studies in patients undergoing major colorectal surgery have shown no significant reduction in postoperative infection rates [24-26]. In each study, however, the effectiveness may have been limited by a relatively short postoperative period of probiotic administration ( 4 to 5 days). In contrast, several studies in patients undergoing pancreatic resection $[27,28]$ and hepatic resection $[29,30]$ have shown significant reductions in postoperative infection rates of up to $30 \%$. These patients received probiotic for 8 to 14 days postoperatively.

Liver transplant patients have multiple risk factors for infection, including profound immunosuppression. Two randomised trials have shown probiotics to be safe and effective in this group of patients. In the first study 95 patients were randomised to receive standard enteral feed plus selective bowel decontamination, fibre-containing enteral feed plus live L. plantarum 299 (Lp299) or fibre-containing enteral feed plus heat-killed Lp299 [31]. The live Lp299 group developed significantly fewer infections than the other two groups ( $48 \%$ vs. $13 \%$ vs. $34 \%$, respectively). In addition, the mean duration of antibiotic 
therapy, the mean total hospital stay and the length of ICU stay were also shorter than in the groups with inactivated Lp299 and selective bowel decontamination. However, these differences did not reach statistical significance. The second study compared only Synbiotic 2000 and prebiotic fibre, reporting postoperative infection rates of $3 \%$ and $48 \%$, respectively [32]. No serious side effects or infections caused by the probiotics were noted in either study.

Oláh and colleagues randomised 45 patients with severe acute pancreatitis to receive enteral oat fibre and live Lp299 or enteral oat fibre and heat-killed Lp299 [33]. In the group treated with the live probiotic, only one patient required surgery for a septic complication involving the pancreas, compared with seven such complications in the control group $(P=0.02)$. There was also a nonsignificant trend toward a shorter length of hospital stay (13.7 days vs. 21.4 days, respectively). The same group carried out a single-centre, double-blind, randomised placebo-controlled trial using Synbiotic 2000 in a further 62 patients with severe acute pancreatitis [34]. This trial showed no statistically significant differences in the incidence of mortality, septic complications or development of multiorgan failure between the two groups. However, the total incidence of systemic inflammatory response syndrome, multiple organ failure and rate of complications was significantly less in the treatment group versus the control group ( 8 vs. $14, P<0.05$ and $P<0.05$, respectively).

The trial that has raised most concern with regard to adverse outcomes and the use of probiotics is the PROPATRIA trial [35]. In this multicentre, placebocontrolled trial, 296 patients with predicted severe acute pancreatitis were randomised to receive the synbiotic preparation Ecologic 641 or placebo. This was administered together with fibre-enriched enteral feed via the nasojejunal route for 28 days. The rate of infectious complications was similar in both groups (30\% vs. $28 \%)$ but the mortality rate was higher in the synbiotic group. Nine patients in the synbiotic group developed bowel ischaemia, eight of these being small bowel ischaemia. There were no cases of bowel ischaemia in the placebo group. One possible explanation for this outcome is a difference in the two groups, with more patients in the synbiotic group having established organ failure at the time treatment began. Another theory is that such a significant intestinal burden of bacteria and high-fibre feed could result in increased oxygen consumption and local bowel ischaemia. Nevertheless, this is the first time such a complication has been reported.

\section{Probiotics in the prevention of respiratory infection}

The respiratory tract is consistently the most common site of nosocomial infection, accounting for $65 \%$ of
ICU-acquired infections [36]. Ventilator-associated pneumonia (VAP) complicates the care of up to $30 \%$ of patients receiving mechanical ventilation, accounting for 50 to $60 \%$ of total antibiotic days [37-40]. Patients with VAP present increased morbidity and mortality, prolonged ICU and hospital lengths of stay, and increased costs [41].

Current VAP prevention strategies aim to reduce colonisation of the oropharynx and upper gastrointestinal tract with pathogenic bacteria and prevent their subsequent aspiration. These measures include elevation of the head of the bed, silver-coated tracheal tubes, oral care, subglottic secretion drainage and use of sedation breaks and weaning protocols. Selective digestive tract decontamination using antibiotics in the oral cavity or whole gastrointestinal tract decontamination have been shown to reduce rates of VAP and mortality [42,43]. However, these strategies have not gained widespread favour in critical care owing to concerns about promoting antibiotic resistance. Oostdijk's group demonstrated a statistically significant increase in intestinal colonisation with Gram-negative bacteria resistant to ceftazidime, tobramycin or ciprofloxacin $(P<0.05)$ [44]. These concerns were also borne out by a large-cluster, randomised cross-over study of selective decontamination of the digestive tract that showed a marked increase resistance to ceftazidime in faecal Enterobacteriaceae, together with a small but significant increase in bacterial resistance from the respiratory tract [45]. In a previous study, the use of cefotaxime as part of selective decontamination of the digestive tract regime was found to select for an outbreak of extended-spectrum $\beta$-lactamase-producing E. coli and Klebsiella pneumonia [46].

To date there have been eight randomised controlled trials of probiotic therapy as a strategy to prevent VAP [38,47-53]. The inclusion criteria, sample size (range 50 to 348), populations studied and diagnostic criteria for VAP varied between studies. The probiotic formula, dosing and route of administration also varied but all trials contained Lactobacillus spp. (see Table 3). Six of the eight trials showed a lower incidence of VAP in the probiotic group [38,47,48,50-52], but this difference was statistically significant in only three of the studies $[38,47,48]$. Interestingly, one study used chlorhexidine oral disinfection as a control and found that probiotic Lp299 was at least as effective in preventing oropharyngeal colonisation $(61.9 \%$ vs. $34.8 \%$ new colonisation, respectively; $P=0.13$ ) [50]. The study by Forestier and colleagues found no difference in incidence of VAP between groups but did demonstrate a median delay in respiratory colonisation with Pseudomonas aeruginosa of 50 days versus 11 days in controls $(P=0.01)$ [49]. This is the most commonly isolated antibiotic-resistant Gramnegative species in VAP [39]. 


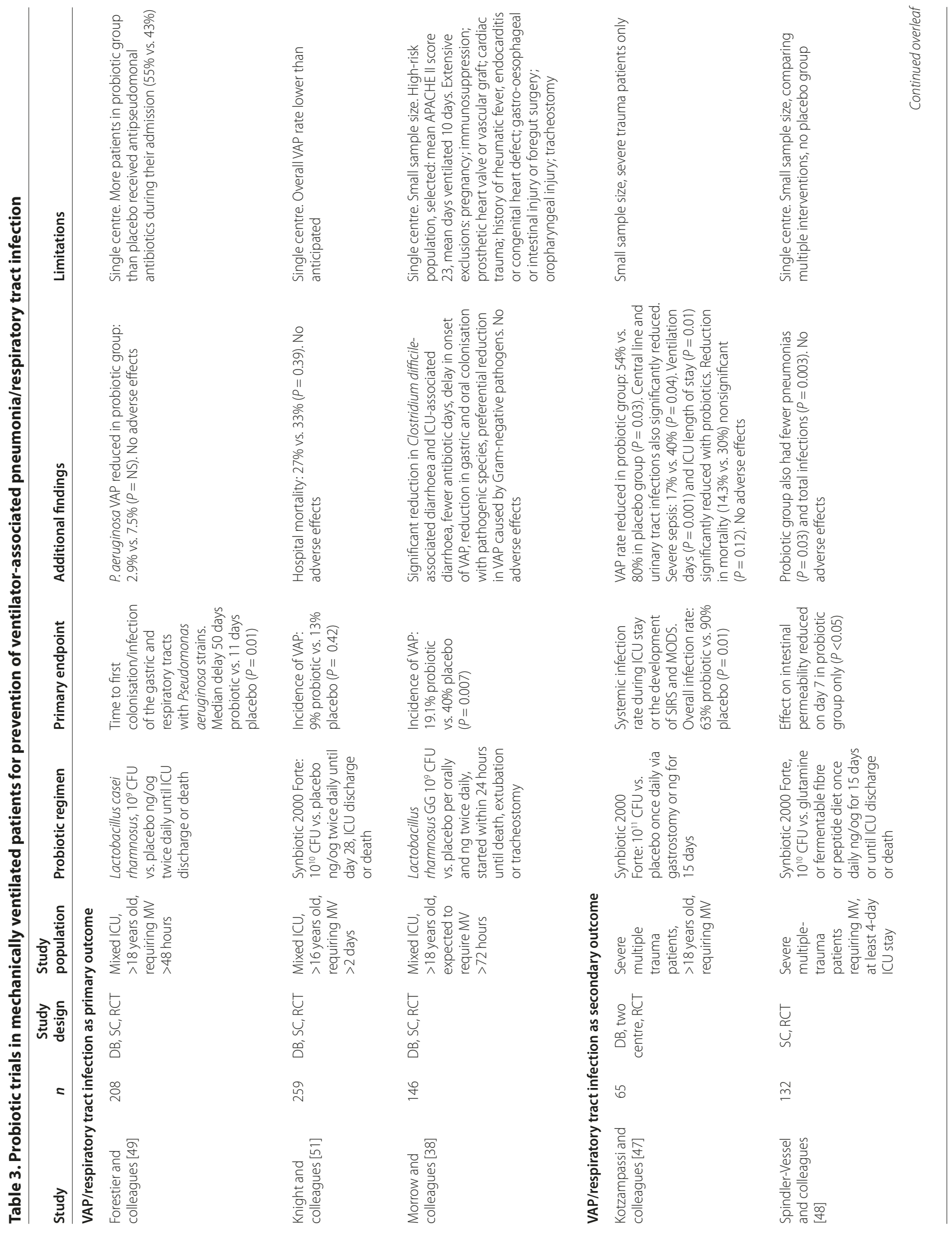




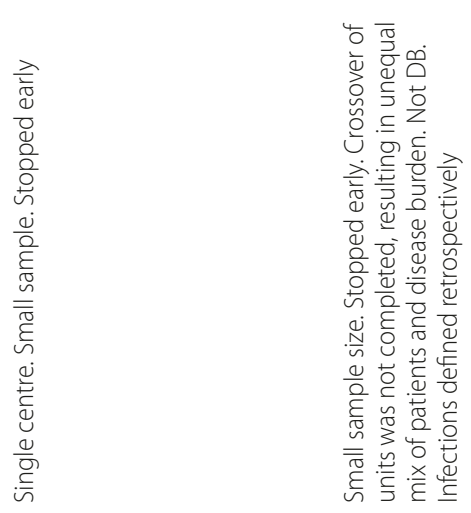

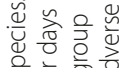

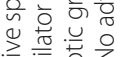

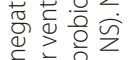

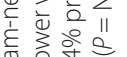

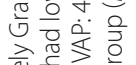

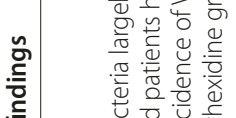

苋通语

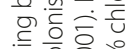

क्.

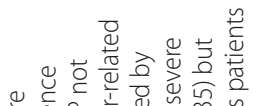

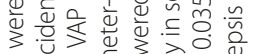

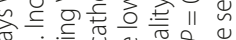

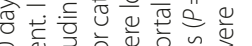

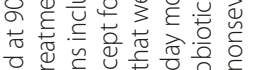

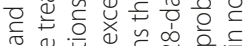

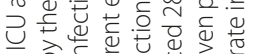

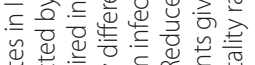

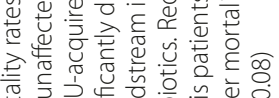

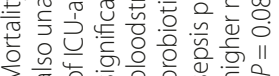

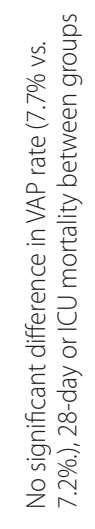

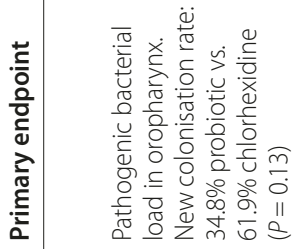

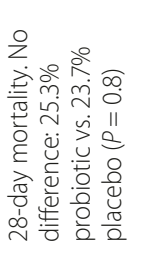

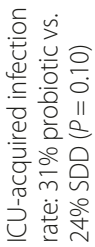

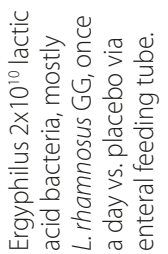

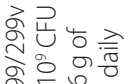

万े

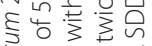

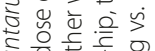

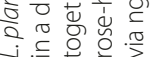

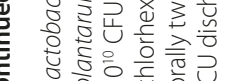

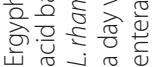

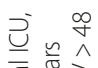

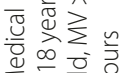

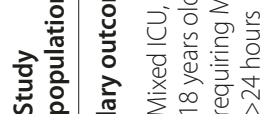

$\sum_{\Sigma}^{\infty} \frac{\infty}{\wedge}$ 흥

흘

政

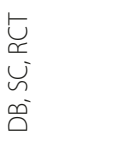

ن.

을

$\underline{6}$

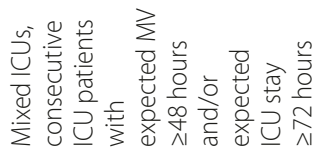

这蓠离

空 응

范
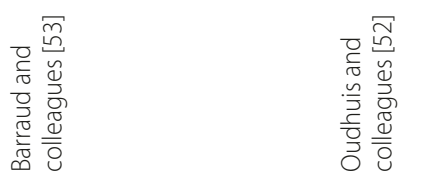
Conflicting results also arise from meta-analyses of probiotics in critical care. The work by Watkinson and colleagues in 2007 analysed the use of prebiotics, probiotics and synbiotics in 999 adult critical care patients from eight randomised controlled trials and concluded that there was no benefit in the probiotic prophylaxis of VAP [54]. In 2010, however, Siempos and colleagues examined five randomised controlled trials (689 patients) and showed that probiotic administration was associated with a lower incidence of VAP when compared with standard care (odds ratio $=0.61 ; 95 \%$ confidence interval $=$ 0.31 to 0.91 ) [55]. Importantly, both of these were published before the studies by Morrow and colleagues [38], Oudhuis and colleagues [52] and Barraud and colleagues [52].

The trial by Morrow and colleagues is unique in that it included oropharyngeal slurry as one of the routes of administration for the probiotic [38]. The research group randomised 146 ventilated patients who were considered at high risk for VAP to receive probiotic L. rhamnosus GG or placebo (inulin) within 24 hours of intubation until extubation, tracheostomy or death. The primary outcome was microbiologically confirmed VAP based on quantitative culture of distal airway samples obtained by bronchoscopy. The incidence of VAP was significantly reduced in the probiotic group (19.1\% with probiotic vs. $40.0 \%$ with placebo, $P=0.007)$.

Morrow and colleagues also examined the incidence of Clostridium difficile and ICU-associated diarrhoea in their patients. The probiotic group had significantly less C. difficile cytotoxin-positive diarrhoea compared with the placebo group (5.6\% vs. $18.6 \%, P=0.02)$, although the duration of diarrhoea was not significantly lower. However, patients treated with probiotic received fewer days of antibiotics for $C$. difficile-associated diarrhoea $(0.5 \pm 2.3$ days vs. $2.1 \pm 4.8$ days in placebo group, $P=0.02)$. The duration of ICU-associated diarrhoea was also significantly reduced in the probiotic group (4.1 \pm 3.7 days vs. $5.9 \pm 3.8$ days in placebo group, $P=0.03$ ).

The rates of oral colonisation with pathogenic species at 72 hours (70\% for placebo vs. $38.2 \%$ for Lactobacillus, $P<0.001)$ correlated with development of VAP (Pearson correlation coefficient $=0.22, P=0.009)$. Interestingly, the probiotic treatment appeared to preferentially reduce rates of infection caused by Gram-negative pathogens (22.8\% for placebo vs. $8.8 \%$ for Lactobacillus, $P=0.02$ ) while having no statistically significant effect on Grampositive species $(12.8 \%$ vs. $5.8 \%, P=0.16)$.

To date, studies of probiotics in the critically ill have trialled a number of species, Lactobacillus featuring frequently. Currently unknown, however, is whether one species is superior in the prevention of infection associated with critical illness. Similarly, the optimal administration route, dosage and duration of treatment are not clear. Further research is undoubtedly warranted, perhaps considering Gram-negative probiotic species.

\section{Administration of probiotics and monitoring of their effects}

Probiotics are commercially available in various preparations including yoghurt-based products, capsules, powders and suspensions. The studies in critically ill patients discussed above involve enteral administration of a variety of probiotic strains using different dosing regimes.

In eight of the nine studies involving mechanically ventilated patients (Table 3), probiotic powder or capsule contents were dissolved in water and delivered via a feeding tube into the stomach. Morrow and colleagues used an oropharyngeal slurry of L. rhamnosus GG (suspended in a sterile water-based surgical lubricant) in addition to nasogastric administration [38]. After 72 hours, the patients receiving this regime were found to have lower rates of oral $(38.2 \%$ vs. $70 \%, P=0.001)$ and gastric $(32.3 \%$ vs. $45.7 \%, P=0.03)$ colonisation with pathogenic species than those receiving placebo. Klarin and colleagues used topical application of Lp299 to the oral cavity alone and found it to be at least as effective as chlorhexidine $0.1 \%$ in reducing oropharyngeal pathogenic load [50].

Testing for colonisation of the gastrointestinal tract with the probiotic species is reported in only a minority of studies. McNaught and colleagues collected gastric aspirates at induction of anaesthesia in elective surgical patients who had received at least 1 week of oral Lp299 [24]. The probiotic species was not isolated in any subject. In the study by Forestier and colleagues, however, gastric aspirates were taken at inclusion, at day 7 and at discharge. Lactobacillus casei rhamnosus was detected in 52 out of 102 patients on probiotic treatment after a median of 13 days [49]. In the study by Klarin and colleagues described above, the probiotic species Lp299 was detected in all oropharyngeal cultures and in the tracheal cultures from $56 \%$ of patients in the probiotic arm [50]. Knight and colleagues demonstrated detection of probiotic species in stool culture after 3 days treatment with Synbiotic 2000 Forte, indicating its survival from the stomach to the distal gut [56]. However, they did not routinely analyse stool samples in their more recent study [51]. None of the other studies cited in Table 3 reported detection of probiotic species in any microbiological specimens.

\section{Quality and safety}

Probiotics are now widely available and are being consumed daily in large quantities. Overall they have an excellent safety record, but there are some concerns that are likely to lead to caution in their widespread use in clinical practice. 
The availability of different probiotics varies from country to country and there can be lack of consistency between manufacturers, and even batches, in terms of density of bacteria, adhesion characteristics, stability and viability [57]. Strain-specific adhesion properties and viability have been shown to vary between batches from the same manufacturer, which could lead to conflicting clinical trial results [58].

There have been a number of publications reporting serious infections caused by Lactobacillus spp. related to those used as probiotics [59]. The Finnish group of Salminen and colleagues examined 89 cases of Lactobacillus bacteraemia. In 11 cases, the strain was identical with the probiotic L. rhamnosus GG [60]. However, they could not directly relate these cases to probiotic consumption. Salminen and colleagues also examined trends in Lactobacillus bacteraemia in Finland over the period 1990 to 2000. This period coincided with a rapid increase in the consumption of probiotic L. rhamnosus GG. The group concluded that increased probiotic use had not led to an increase in Lactobacillus bacteraemia [61].

There are case reports in the literature of Lactobacillus infection and bacteraemia that appear to be directly related to probiotic consumption [62-65]. All of the patients involved were immunocompromised to some degree and the causative organism was linked to the probiotic by molecular techniques. Infections caused by Lactobacillus spp. from probiotics have also been reported in immunosuppressed patients - including those with acquired immunodeficiency syndrome and those following lung and liver transplantation [66-68]. Lactobacillus bacteraemia has been associated with structural heart abnormalities, valve prosthesis or prior endocarditis [69]. However, the majority of clinical trials using Lactobacillus spp. probiotics report few adverse effects.

The only reported infection associated with probiotic E. coli Nissle 1917 is in a premature neonate (gestational age 28 weeks) [70]. The child had an extremely low birth weight of $935 \mathrm{~g}$ and developed gastroenteritis due to rotavirus and adenovirus 14 days into the postnatal period. E. coli Nissle treatment initially led to improvement but the child developed severe sepsis 10 days later and subsequently E. coli Nissle 1917 was isolated in blood cultures. The child was treated with antibiotics and made a full recovery.

A wide range of probiotic species is being investigated for an increasing number of indications. There has been little work carried out on the rationale behind which probiotics are used and in what combination. Timmerman and colleagues attempted to address this issue by examining specific strains in an attempt to produce an effective multispecies mixture [71]. The symbiotic preparation Ecologic 641 was used in the PROPATRIA trial. This group selected six strains of Lactobacillus based on survival in a simulated gastrointestinal environment, antimicrobial activity and ability to induce IL-10, highlighting the point that there should be a diseasespecific rationale for selection of probiotics.

\section{Conclusions}

Concerns are mounting about multidrug-resistant Gramnegative bacteria with the extensive spread of extendedspectrum $\beta$-lactamases [72], and in particular the emergence of Enterobacteriaceae with resistance to carbapenems conferred by metallo- $\beta$-lactamase NDM-1 [73]. New antimicrobial agents with which to tackle resistant bacteria are in limited supply, and a recently announced EU-US taskforce has called for a commitment to the development of 10 new antibacterial agents by 2020 . This will require a substantial public financial investment and will need to be sustained long term because continued antibiotic use will maintain the pressure on organisms to evolve new resistant strains. In the absence of universally effective treatments, strategies that could prevent the development of ICU-acquired infection are needed.

The human, animal and in vitro studies of probiotics carried out to date exhibit a high level of heterogeneity in the conditions targeted, models used and probiotics tested. These studies are likely to reflect an oversimplistic view of the mechanisms of action of probiotic species. As alluded to above, probiotics are likely to bring about their effects through multiple processes with different strains having very specific effects.

We are still far from understanding fully the probiotichost interaction but, given the potential benefits that probiotic bacteria have to offer, further study is warranted. Careful consideration should be given to further well-powered studies addressing the questions of which probiotic by what route, in what dose and at what time.

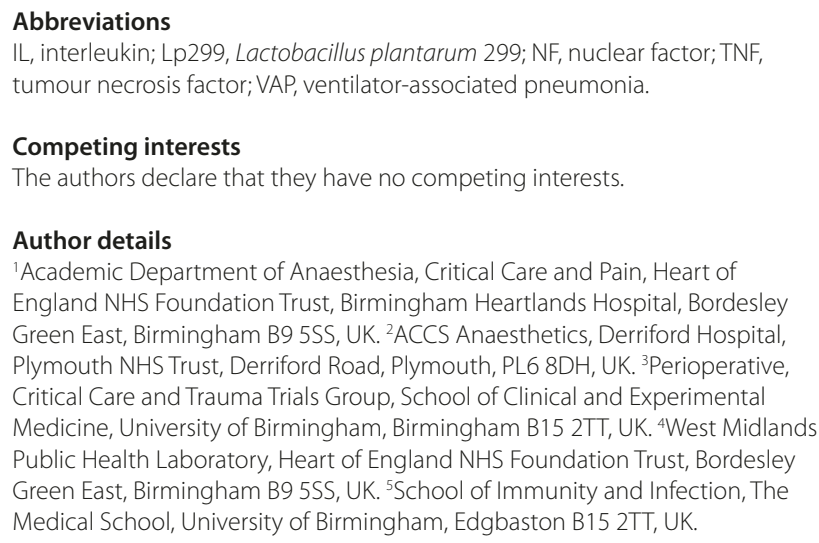

Published: 5 November 2012 


\section{References}

1. Alverdy JC, Laughlin RS, Wu L: Influence of the critically ill state on hostpathogen interactions within the intestine: gut-derived sepsis redefined. Crit Care Med 2003, 31:598-607.

2. Bengmark S: Synbiotics to strengthen gut barrier function and reduce morbidity in critically ill patients. Clin Nutr 2004, 23:441-445.

3. MacFie J, O'Boyle C, Mitchell CJ, Buckley PM, Johnstone D, Sudworth P: Gut origin of sepsis: a prospective study investigating associations between bacterial translocation, gastric microflora, and septic morbidity. Gut 1999 45:223-228

4. Hassoun HT, Kone BC, Mercer DW, Moody FG, Weisbrodt NW, Moore FA: Post-injury multiple organ failure: the role of the gut. Shock 2001, 15:1-10.

5. Sherman PM, Ossa JC, Johnson-Henry K: Unraveling mechanisms of action of probiotics. Nutr Clin Pract 2009, 24:10-14.

6. Guarner F, Khan AG, Garisch J, Eliakim R, Gangl A, Thomson A, et al.: World gastroenterology organisation global guidelines: probiotics and prebiotics october 2011. J Clin Gastroentero/ 2012, 46:468-481.

7. Gibson GR, Roberfroid MB: Dietary modulation of the human colonic microbiota: introducing the concept of prebiotics. J Nutr 1995, 125:1401-1412.

8. Arumugam M, Raes J, Pelletier E, Le Paslier D, Yamada T, Mende DR, Fernandes GR, Tap J, Bruls T, Batto J-M, Bertalan M, Borruel N, Casellas F, Fernandez L, Gautier L, Hansen T, Hattori M, Hayashi T, Kleerebezem M, Kurokawa K, Leclerc M, Levenez F, Manichanh C, Nielsen HB, Nielsen T, Pons N, Poulain J, Qin J, Sicheritz-Ponten T, Tims S, et al:: Enterotypes of the human gut microbiome. Nature 2011, 473:174-180.

9. Qin J, Li R, Raes J, Arumugam M, Burgdorf KS, Manichanh C, Nielsen T, Pons N, Levenez F, Yamada T, Mende DR, Li J, Xu J, Li S, Li D, Cao J, Wang B, Liang H, Zheng H, Xie Y, Tap J, Lepage P, Bertalan M, Batto J-M, Hansen T, Le Paslier D, Linneberg A, Nielsen HB, Pelletier E, Renault $P$, et al: A human gut microbial gene catalogue established by metagenomic sequencing. Nature 2010, 464:59-65.

10. Sepp E, Mikelsaar M, Salminen S: Effect of administration of Lactobacillus casei strain GG on the gastrointestinal microbiota of newborns. Microb Ecol Health Dis 1993, 6:309-314

11. Benno $Y$, He F, Hosoda M, Hashimoto H, Kojima T, Yamazaki K, lino H, Mykkanen H, Salminen S: Effect of Lactobacillus GG yoghurt on human intestinal microecology in Japanese subjects. Nutr Today 1996, 31(Suppl 1):9s-11s.

12. Fayol-Messaoudi D, Berger CN, Coconnier-Polter M-H, Liévin-Le Moal V, Servin $\mathrm{AL}: \mathrm{pH}$-, lactic acid-, and non-lactic acid-dependent activities of probiotic Lactobacilli against Salmonella enterica Serovar Typhimurium. Appl Environ Microbiol 2005, 71:6008-6013.

13. Venturi A, Gionchetti P, Rizzello F, Johansson R, Zucconi E, Brigidi P, Matteuzzi $D$, Campieri M: Impact on the composition of the faecal flora by a new probiotic preparation: preliminary data on maintenance treatment of patients with ulcerative colitis. Aliment Pharmacol Ther 1999, 13:1103-1108

14. Corr SC, Li Y, Riedel CU, O'Toole PW, Hill C, Gahan CGM: Bacteriocin production as a mechanism for the antiinfective activity of Lactobacillus salivarius UCC118. Proc Natl Acad Sci U S A 2007, 104:7617-7621.

15. Ng SC, Hart AL, Kamm MA, Stagg AJ, Knight SC: Mechanisms of action of probiotics: recent advances. Inflamm Bowel Dis 2009, 15:300-310.

16. Flynn $S$, van Sinderen D, Thornton GM, Holo H, Nes IF, Collins JK: Characterization of the genetic locus responsible for the production of ABP-118, a novel bacteriocin produced by the probiotic bacterium Lactobacillus salivarius subsp. salivarius UCC118. Microbiology 2002 148:973-984.

17. Medellin-Peña MJ, Wang H, Johnson R, Anand S, Griffiths MW: Probiotics affect virulence-related gene expression in Escherichia coli 0157:H7. Appl Environ Microbiol 2007, 73:4259-4267.

18. Mack DR, Michail S, Wei S, McDougall L, Hollingsworth MA: Probiotics inhibit enteropathogenic E. coli adherence in vitro by inducing intestinal mucin gene expression. Am J Physio/ 1999, 276:G941-G950.

19. Walker WA: Mechanisms of action of probiotics. Clin Infect Dis 2008 46(Suppl 2):S87-S91; discussion S144-S151

20. Allen SJ, Okoko B, Martinez E, Gregorio G, Dans LF: Probiotics for treating infectious diarrhoea. Cochrane Database Syst Rev 2004 2:CD003048.

21. Gatt M, Reddy BS, MacFie J: Review article: bacterial translocation in the critically ill - evidence and methods of prevention. Aliment Pharmacol Ther 2007, 25:741-757.

22. Shimizu K, Ogura H, Hamasaki T, Goto M, Tasaki O, Asahara T, Nomoto K,
Morotomi M, Matsushima A, Kuwagata Y, Sugimoto H: Altered gut flora are associated with septic complications and death in critically ill patients with systemic inflammatory response syndrome. Dig Dis Sci 2011, 56:1171-1177.

23. Inglis TJJ, Sherratt MJ, Sproat LJ, Hawkey PM, Gibson JS: Gastroduodenal dysfunction and bacterial colonisation of the ventilated lung. The Lancet 1993, 341:911-913.

24. McNaught CE, Woodcock NP, MacFie J, Mitchell CJ: A prospective randomised study of the probiotic Lactobacillus plantarum 299V on indices of gut barrier function in elective surgical patients. Gut 2002, 51:827-831.

25. Anderson ADG, McNaught CE, Jain PK, MacFie J: Randomised clinical trial of synbiotic therapy in elective surgical patients. Gut 2004, 53:241-245.

26. Reddy BS, Macfie J, Gatt M, Larsen CN, Jensen SS, Leser TD: Randomized clinical trial of effect of synbiotics, neomycin and mechanical bowel preparation on intestinal barrier function in patients undergoing colectomy. Br J Surg 2007, 94:546-554.

27. Nomura T, Tsuchiya Y, Nashimoto A, Yabusaki H, Takii Y, Nakagawa S, Sato N, Kanbayashi C, Tanaka O: Probiotics reduce infectious complications after pancreaticoduodenectomy. Hepatogastroenterology 2007, 54:661-663.

28. Rayes N, Seehofer D, Theruvath T, Mogl M, Langrehr JM, Nüssler NC, Bengmark S, Neuhaus P: Effect of enteral nutrition and synbiotics on bacterial infection rates after pylorus-preserving pancreatoduodenectomy: a randomized, double-blind trial. Ann Surg 2007, 246:36-41

29. Kanazawa H, Nagino M, Kamiya S, Komatsu S, Mayumi T, Takagi K, Asahara T, Nomoto K, Tanaka R, Nimura Y: Synbiotics reduce postoperative infectious complications: a randomized controlled trial in biliary cancer patients undergoing hepatectomy. Langenbecks Arch Surg 2005, 390:104-113.

30. Sugawara G, Nagino M, Nishio H, Ebata T, Takagi K, Asahara T, Nomoto K, Nimura Y: Perioperative synbiotic treatment to prevent postoperative infectious complications in biliary cancer surgery: a randomized controlled trial. Ann Surg 2006, 244:706-714.

31. Rayes N, Seehofer D, Hansen S, Boucsein K, Müller AR, Serke S, Bengmark S, Neuhaus P: Early enteral supply of lactobacillus and fiber versus selective bowel decontamination: a controlled trial in liver transplant recipients. Transplantation 2002, 74:123-127.

32. Rayes N, Seehofer D, Theruvath T, Schiller RA, Langrehr JM, Jonas S, Bengmark $S$, Neuhaus P: Supply of pre- and probiotics reduces bacterial infection rates after liver transplantation - a randomized, double-blind trial. Am J Transplant 2005, 5:125-130.

33. Oláh A, Belágyi T, Issekutz A, Gamal ME, Bengmark S: Randomized clinical trial of specific lactobacillus and fibre supplement to early enteral nutrition in patients with acute pancreatitis. Br J Surg 2002, 89:1103-1107.

34. Oláh A, Belágyi T, Pótó L, Romics L Jr, Bengmark S: Synbiotic control of inflammation and infection in severe acute pancreatitis: a prospective, randomized, double blind study. Hepatogastroenterology 2007, 54:590-594

35. Besselink MGH, van Santvoort HC, Buskens E, Boermeester MA, van Goor H, Timmerman HM, Nieuwenhuijs VB, Bollen TL, van Ramshorst B, Witteman BJM, Rosman C, Ploeg RJ, Brink MA, Schaapherder AFM, Dejong CHC, Wahab PJ, van Laarhoven CJHM, van der Harst E, van Eijck CHJ, Cuesta MA, Akkermans LMA, Gooszen HG: Probiotic prophylaxis in predicted severe acute pancreatitis: a randomised, double-blind, placebo-controlled trial. Lancet 2008, 371:651-659.

36. Vincent JL, Bihari DJ, Suter PM, Bruining HA, White J, Nicolas-Chanoin MH, Wolff M, Spencer RC, Hemmer M: The prevalence of nosocomial infection in intensive care units in Europe. Results of the European Prevalence of Infection in Intensive Care (EPIC) Study. EPIC International Advisory Committee. JAMA 1995, 274:639-644.

37. Vincent J-L, Rello J, Marshall J, Silva E, Anzueto A, Martin CD, Moreno R, Lipman J, Gomersall C, Sakr Y, Reinhart K: International study of the prevalence and outcomes of infection in intensive care units. JAMA 2009, 302:2323-2329.

38. Morrow LE, Kollef MH, Casale TB: Probiotic prophylaxis of ventilatorassociated pneumonia: a blinded, randomized, controlled trial. Am J Respir Crit Care Med 2010, 182:1058-1064.

39. Guidelines for the management of adults with hospital-acquired ventilator-associated, and healthcare-associated pneumonia. Am J Respir Crit Care Med 2005, 171:388-416.

40. Vincent J-L, Sakr Y, Sprung CL, Ranieri VM, Reinhart K, Gerlach H, Moreno R, Carlet J, Le Gall J-R, Payen D: Sepsis in European intensive care units: results 
of the SOAP study. Crit Care Med 2006, 34:344-353.

41. Kollef MH, Shorr A, Tabak YP, Gupta V, Liu LZ, Johannes RS: Epidemiology and outcomes of health-care-associated pneumonia: results from a large US database of culture-positive pneumonia. Chest 2005, 128:3854-3862.

42. Liberati A, D'Amico R, Pifferi S, Torri V, Brazzi L, Parmelli E: Antibiotic prophylaxis to reduce respiratory tract infections and mortality in adults receiving intensive care. Cochrane Database Syst Rev 2009 4:CD000022.

43. de Smet AMGA, Kluytmans JAJW, Cooper BS, Mascini EM, Benus RFJ, van der Werf TS, van der Hoeven JG, Pickkers P, Bogaers-Hofman D, van der Meer NJM, Bernards AT, Kuijper EJ, Joore JCA, Leverstein-van Hall MA, Bindels AJGH, Jansz AR, Wesselink RMJ, de Jongh BM, Dennesen PJW, van Asselt GJ, te Velde LF, Frenay IHME, Kaasjager K, Bosch FH, van Iterson M, Thijsen SFT, Kluge GH, Pauw W, de Vries JW, Kaan JA, et al: Decontamination of the digestive tract and oropharynx in ICU patients. NEng/ J Med 2009, 360:20-31.

44. Oostdijk EAN, de Smet AMGA, Blok HEM, Thieme Groen ES, van Asselt GJ, Benus RFJ, Bernards SAT, Frénay IHME, Jansz AR, de Jongh BM, Kaan JA, Leverstein-van Hall MA, Mascini EM, Pauw W, Sturm PDJ, Thijsen SFT, Kluytmans JAJW, Bonten MJM: Ecological effects of selective decontamination on resistant gram-negative bacterial colonization. Am J Respir Crit Care Med 2010, 181:452-457.

45. García-San Vicente B, Canut A, Labora A, Otazua M, Corral E: [Selective decontamination of the digestive tract: repercussions on microbiology laboratory workload and costs, and antibiotic resistance trends]. Enferm Infecc Microbiol Clin 2010, 28:75-81.

46. Al Naiemi N, Heddema ER, Bart A, de Jonge E, Vandenbroucke-Grauls CM, Savelkoul PHM, Duim B: Emergence of multidrug-resistant Gram-negative bacteria during selective decontamination of the digestive tract on an intensive care unit. J Antimicrob Chemother 2006, 58:853-856.

47. Kotzampassi K, Giamarellos-Bourboulis EJ, Voudouris A, Kazamias P, Eleftheriadis E: Benefits of a synbiotic formula (Synbiotic 2000Forte) in critically III trauma patients: early results of a randomized controlled trial. World J Surg 2006, 30:1848-1855.

48. Spindler-Vesel A, Bengmark S, Vovk I, Cerovic O, Kompan L: Synbiotics, prebiotics, glutamine, or peptide in early enteral nutrition: a randomized study in trauma patients. JPEN J Parenter Enteral Nutr 2007, 31:119-126.

49. Forestier C, Guelon D, Cluytens V, Gillart T, Sirot J, De Champs C: Oral probiotic and prevention of Pseudomonas aeruginosa infections: a randomized, double-blind, placebo-controlled pilot study in intensive care unit patients. Crit Care 2008, 12:R69.

50. Klarin B, Molin G, Jeppsson B, Larsson A: Use of the probiotic Lactobacillus plantarum 299 to reduce pathogenic bacteria in the oropharynx of intubated patients: a randomised controlled open pilot study. Crit Care 2008, 12:R136

51. Knight DJW, Gardiner D, Banks A, Snape SE, Weston VC, Bengmark S, Girling $\mathrm{KJ}$ : Effect of synbiotic therapy on the incidence of ventilator associated pneumonia in critically ill patients: a randomised, double-blind, placebocontrolled trial. Intensive Care Med 2009, 35:854-861.

52. Oudhuis GJ, Bergmans DC, Dormans T, Zwaveling J-H, Kessels A, Prins MH, Stobberingh EE, Verbon A: Probiotics versus antibiotic decontamination of the digestive tract: infection and mortality. Intensive Care Med 2011 37:110-117.

53. Barraud D, Blard C, Hein F, Marçon O, Cravoisy A, Nace L, Alla F, Bollaert P-E, Gibot S: Probiotics in the critically ill patient: a double blind, randomized, placebo-controlled trial. Intensive Care Med 2010, 36:1540-1547.

54. Watkinson PJ, Barber VS, Dark P, Young JD: The use of pre- pro- and synbiotics in adult intensive care unit patients: systematic review. Clin Nutr 2007, 26:182-192

55. Siempos II, Ntaidou TK, Falagas ME: Impact of the administration of probiotics on the incidence of ventilator-associated pneumonia: a metaanalysis of randomized controlled trials. Crit Care Med 2010, 38:954-962.

56. Knight D, Ala'Aldeen D, Bengmark S, Girling K: The effect of probiotics on gastrointestinal flora in the critically ill. Br J Anaesth 2004, 92:307-308.

57. Tuomola E, Crittenden R, Playne M, Isolauri E, Salminen S: Quality assurance criteria for probiotic bacteria. Am J Clin Nutr 2001, 73:393S-398S.

58. Clements ML, Levine MM, Ristaino PA, Daya VE, Hughes TP: Exogenous lactobacilli fed to man - their fate and ability to prevent diarrheal disease. Prog Food Nutr Sci 1983, 7:29-37.

59. Isakow W, Morrow LE, Kollef MH: Probiotics for preventing and treating nosocomial infections: review of current evidence and recommendations. Chest 2007, 132:286-294

60. Salminen MK, Rautelin H, Tynkkynen S, Poussa T, Saxelin M, Valtonen V, et al:
Lactobacillus bacteremia, clinical significance, and patient outcome, with special focus on probiotic L. rhamnosus GG. Clin Infect Dis 2004, 38:62-69.

61. Salminen MK, Tynkkynen S, Rautelin H, Saxelin M, Vaara M, Ruutu P, et al: Lactobacillus bacteremia during a rapid increase in probiotic use of Lactobacillus rhamnosus GG in Finland. Clin Infect Dis 2002, 35:1155-1160.

62. Rautio M, Jousimies-Somer H, Kauma H, Pietarinen I, Saxelin M, Tynkkynen S, Koskela M: Liver abscess due to a Lactobacillus rhamnosus strain indistinguishable from L. rhamnosus strain GG. Clin Infect Dis 1999, 28:1159-1160.

63. Mackay A, Taylor M, Kibbler C, Hamilton-Miller J: Lactobacillus endocarditis caused by a probiotic organism. Clin Microbiol Infect 1999, 5:290-292

64. Kunz A, Noel J, Fairchok M: Two cases of Lactobacillus bacteremia during probiotic treatment of short gut syndrome. J Pediatr Gastroenterol Nutr 2004, 38:457-458

65. Land M, Rouster-Stecens K, Woods C, Cannon M, Cnota J, Shetty A: Lactobacillus sepsis associated with probiotic therapy. Pediatrics 2005 , 115:178-181.

66. Abgrall S, Joly V, Derkinderen P, Decré D, Carbon C, Yeni P: Lactobacillus casei infection in an AIDS patient. Eur J Clin Microbiol Infect Dis 1997, 16:180-182.

67. Jones SD, Fullerton DA, Zamora MR, Badesch DB, Campbell DN, Grover FL: Transmission of Lactobacillus pneumonia by a transplanted lung. Ann Thorac Surg 1994, 58:887-889.

68. Patel R, Cockerill FR, Porayko MK, Osmon DR, Ilstrup DM, Keating MR: Lactobacillemia in liver transplant patients. Clin Infect Dis 1994, 18:207-212

69. Saxelin M, Chuang NH, Chassy B, Rautelin H, Mäkelä PH, Salminen S, Gorbach SL: Lactobacilli and bacteremia in southern Finland, 1989-1992. Clin Infect Dis 1996, 22:564-566.

70. Guenther K, Straube E, Pfister W, Guenther A, Huebler A: Severe sepsis after probiotic treatment with Escherichia coli NISSLE 1917. Pediatr Infect Dis 」 2010, 29:188-189.

71. Timmerman HM, Niers LEM, Ridwan BU, Koning CIM, Mulder L, Akkermans LMA, Rombouts FM, Rijkers GT: Design of a multispecies probiotic mixture to prevent infectious complications in critically ill patients. Clin Nutr 2007, 26:450-459.

72. Hawkey PM, Jones AM: The changing epidemiology of resistance. J Antimicrob Chemother 2009, 64(Suppl 1):i3-i10

73. Kumarasamy KK, Toleman MA, Walsh TR, Bagaria J, Butt F, Balakrishnan R, Chaudhary U, Doumith M, Giske CG, Irfan S, Krishnan P, Kumar AV, Maharjan S, Mushtaq S, Noorie T, Paterson DL, Pearson A, Perry C, Pike R, Rao B, Ray U, Sarma JB, Sharma M, Sheridan E, Thirunarayan MA, Turton J, Upadhyay S, Warner M, Welfare W, Livermore DM, et al:: Emergence of a new antibiotic resistance mechanism in India, Pakistan, and the UK: a molecular, biological, and epidemiological study. Lancet Infect Dis 2010, 10:597-602.

74. Adlerberth I, Ahrne S, Johansson ML Molin G, Hanson LA, Wold AE: A mannose-specific adherence mechanism in Lactobacillus plantarum conferring binding to the human colonic cell line HT-29. Appl Environ Microbiol 1996, 62:2244-2251.

75. Forestier C, De Champs C, Vatoux C, Joly B: Probiotic activities of Lactobacillus casei rhamnosus: in vitro adherence to intestinal cells and antimicrobial properties. Res Microbiol 2001, 152:167-173.

76. Otte J-M, Podolsky DK: Functional modulation of enterocytes by Grampositive and Gram-negative microorganisms. Am J Physiol Gastrointest Liver Physiol 2004, 286:G613-G626.

77. Wehkamp J, Harder J, Wehkamp K, Wehkamp-von Meissner B, Schlee M, Enders C, Sonnenborn U, Nuding S, Bengmark S, Fellermann K, Schröder JM, Stange EF: NF-kappaB- and AP-1-mediated induction of human beta defensin-2 in intestinal epithelial cells by Escherichia coli Nissle 1917: a novel effect of a probiotic bacterium. Infect Immun 2004, 72:5750-5758.

78. Resta-Lenert S, Barrett KE: Live probiotics protect intestinal epithelial cells from the effects of infection with enteroinvasive Escherichia coli (EIEC). Gut 2003, 52:988-997.

79. Meddings J: The significance of the gut barrier in disease. Gut 2008 57:438-440

80. Sherman PM, Johnson-Henry KC Yeung HP Ngo PSC Goulet J, Tompkins TA: Probiotics reduce enterohemorrhagic Escherichia coli 0157:H7- and enteropathogenic E. coli 0127:H6-induced changes in polarized T84 epithelial cell monolayers by reducing bacterial adhesion and cytoskeletal rearrangements. Infect Immun 2005, 73:5183-5188.

81. Yan F, Polk DB: Probiotic bacterium prevents cytokine-induced apoptosis in intestinal epithelial cells. J Biol Chem 2002, 277:50959-50965.

82. Ichikawa H, Kuroiwa T, Inagaki A, Shineha R, Nishihira T, Satomi S, Sakata T: 
Probiotic bacteria stimulate gut epithelial cell proliferation in rat. Dig Dis Sci 1999, 44:2119-2123.

83. de Champs C, Maroncle N, Balestrino D, Rich C, Forestier C: Persistence of colonization of intestinal mucosa by a probiotic strain, Lactobacillus casei subsp. rhamnosus Lcr35, after oral consumption. J Clin Microbiol 2003, 41:1270-1273.

84. Reissbrodt R, Hammes WP, dal Bello F, Prager R, Fruth A, Hantke K, Rakin A, Starcic-Erjavec M, Williams PH: Inhibition of growth of Shiga toxinproducing Escherichia coli by nonpathogenic Escherichia coli. FEMS Microbiol Lett 2009, 290:62-69.

85. Shi HN, Walker A: Bacterial colonization and the development of intestinal defences. Can J Gastroenterol 2004, 18:493-500.

86. Akira S, Takeda K, Kaisho T: Toll-like receptors: critical proteins linking innate and acquired immunity. Nat Immunol 2001, 2:675-680.

87. Ulisse S, Gionchetti P, D'Alò S, Russo FP, Pesce I, Ricci G, Rizzello F, Helwig U, Cifone MG, Campieri M, De Simone C: Expression of cytokines, inducible nitric oxide synthase, and matrix metalloproteinases in pouchitis: effects of probiotic treatment. Am J Gastroenterol 2001, 96:2691-2699.

88. Pathmakanthan S, Li CKF, Cowie J, Hawkey CJ: Lactobacillus plantarum 299: beneficial in vitro immunomodulation in cells extracted from inflamed human colon. J Gastroenterol Hepatol 2004, 19:166-173.

89. Borruel N, Carol M, Casellas F, Antolín M, de Lara F, Espín E, Naval J, Guarner F, Malagelada JR: Increased mucosal tumour necrosis factor alpha production in Crohn's disease can be downregulated ex vivo by probiotic bacteria. Gut 2002, 51:659-664

90. Arribas B, Rodríguez-Cabezas ME, Camuesco D, Comalada M, Bailón E, Utrilla P, Nieto A, Concha A, Zarzuelo A, Gálvez J: A probiotic strain of Escherichia coli, Nissle 1917, given orally exerts local and systemic anti-inflammatory effects in lipopolysaccharide-induced sepsis in mice. Br J Pharmacol 2009, 157:1024-1033.
91. Kaila M, Isolauri E, Soppi E, Virtanen E, Laine S, Arvilommi H: Enhancement of the circulating antibody secreting cell response in human diarrhea by a human Lactobacillus strain. Pediatr Res 1992, 32:141-144.

92. Isolauri E, Juntunen M, Rautanen T, Sillanaukee P, Koivula T: A human Lactobacillus strain (Lactobacillus casei sp strain $\mathrm{GG}$ ) promotes recovery from acute diarrhea in children. Pediatrics 1991, 88:90-97.

93. Teitelbaum JE, Walker WA: Nutritional impact of pre- and probiotics as protective gastrointestinal organisms. Annu Rev Nutr 2002, 22:107-138.

94. Shida K, Nanno M, Nagata S: Flexible cytokine production by macrophages and T cells in response to probiotic bacteria: a possible mechanism by which probiotics exert multifunctional immune regulatory activities. Gut Microbes 2011, 2:109-114

95. Takeda K, Suzuki T, Shimada S-1, Shida K, Nanno M, Okumura K: Interleukin-12 is involved in the enhancement of human natural killer cell activity by Lactobacillus casei Shirota. Clin Exp Immunol 2006, 146:109-115.

96. Hatcher GE, Lambrecht RS: Augmentation of macrophage phagocytic activity by cell-free extracts of selected lactic acid-producing bacteria. J Dairy Sci 1993, 76:2485-2492.

97. Kruis W, Fric P, Pokrotnieks J, Lukás M, Fixa B, Kascák M, Kamm MA, Weismueller J, Beglinger C, Stolte M, Wolff C, Schulze J: Maintaining remission of ulcerative colitis with the probiotic Escherichia coli Nissle 1917 is as effective as with standard mesalazine. Gut 2004, 53:1617-1623.

doi:10.1186/cc11382

Cite this article as: Crooks NH, et al.: Clinical review: Probiotics in critical care. Critical Care 2012, 16:237. 